\title{
Performance, Nutrient Digestibility, and Meat Quality of Bali Cattle Fed a Ration Supplemented with Soybean Oil Calcium Soap and Cashew Fruit Flour
}

\author{
A. Bain ${ }^{\text {, D. D. A. Astuti }}{ }^{\text {, }}$ S. Suharti ${ }^{\text {, C. Arman }}$, \& K. G. Wiryawan ${ }^{\text {b* }}$ \\ a Graduate Student of Nutrition and Feed Science Study Program, Bogor Agricultural University \\ ${ }^{b}$ Department of Nutrition and Feed Technology, Faculty of Animal Science, Bogor Agricultural University \\ Jalan Agatis, Kampus IPB Darmaga, Bogor, Indonesia \\ 'Faculty of Animal Sciance, Mataram University, Mataram, Indonesia \\ (Received 01-06-2016; Reviewed 06-09-2016; Accepted 23-11-2016)
}

\begin{abstract}
The study to evaluate growth performance, nutrient digestibility, blood metabolites profile and meat fatty acid of Bali cattle treated with 3 different types of rations were conducted using a completely randomized block design with 4 replications. Ration treatments were R1: $40 \%$ native grass (NG) + $60 \%$ concentrate, R2: $40 \%$ NG $+60 \%$ concentrate supplemented with $5 \%$ soybean oil calcium soap (SOCS), and R3: (40\% $\mathrm{NG}+60 \%$ concentrate supplemented with $5 \%$ SOCS $+10 \%$ cashew fruit flour (CFF). Variables measured were growth performance, nutrients digestibility, blood metabolites, and meat fatty acid profile. Data were analyzed using analysis of variance (ANOVA) and the differences between treatment means were examined by Duncan Multiple Range Test. Results of the study showed that the 3 different feed treatments did not have any significant effect on dry matter intake and organic matter intake, daily body weight gain, feed efficiency, crude fiber, ADF and NDF digestibilities, cholesterol, triglycerides, low density lipoprotein (LDL), high density lipoprotein (HDL), total fatty acid contents and content of unsaturated and saturated meat fatty acids of Bali cattle meat. Different treatment rations also did not affect dry matter digestibility, however the treatments significantly affect the organic matter, crude protein, and fat digestibility $(P<0.05)$. Bali cattle fed 5\% SOCS (R2) and 5\% SOCS + 10\% CFF (R3) had higher organic matter and ether extract digestibilities and linoleic acid content of meat $(\mathrm{P}<0.05)$ compared with the control (R1). The Bali cattle fed with R1 and R2 had higher crude protein digestibility $(\mathrm{P}<0.05)$ compared with that of $\mathrm{R} 3$. It is concluded that the supplementation of $5 \%$ SOCS and $10 \%$ CFF in the ration improved the digestibility of organic matter, ether extract and linoleic fatty acids content in Bali cattle meat.
\end{abstract}

Key words: calcium soaps, growth, digestibility, blood metabolites, meat's fatty acid, Bali cattle

\section{ABSTRAK}

Penelitian untuk mengevaluasi performa, kecernaan nutrien, profil metabolit darah, dan kandungan asam lemak daging sapi Bali yang diberi tiga jenis ransum berbeda, dilaksanakan menggunakan rancangan acak kelompok dengan 4 ulangan. Perlakuan ransum terdiri atas R1: $40 \%$ rumput lapang (RL) $+60 \%$ konsentrat, R2: $40 \%$ RL + 60\% konsentrat disuplementasi 5\% sabun kalsium minyak kedelai (SKMK), dan R3: $40 \%$ RL $+60 \%$ konsentrat disuplementasi 5\% SKMK + 10\% tepung buah semu jambu mete (TBSJM). Variabel yang diukur adalah performa pertumbuhan, kecernaan nutrien, profil metabolit darah, dan kandungan asam lemak daging. Data dianalisis menggunakan analysis of varian (ANOVA) dan perbedaan antara perlakuan diuji dengan Duncan's multiple range test. Hasil penelitian menunjukkan bahwa perbedan ransum perlakuan tidak berpengaruh nyata terhadap konsumsi bahan kering, konsumsi bahan organik, pertambahan bobot badan harian, kecernaan serat kasar, ADF dan NDF, kandungan kolesterol, trigliserida, low density lipoprotein (LDL), high density lipoprotein (HDL), kandungan asam lemak total, kandungan asam lemak tak jenuh dan asam lemak tak jenuh daging sapi Bali. Perbedaan ransum perlakuan juga tidak berpengaruh nyata terhadap kecernaan bahan kering, tetapi berpengaruh nyata $(P<0,05)$ terhadap kecernaan bahan organik, kecernaan protein kasar, dan kecernaan lemak kasar. Sapi Bali yang mengkonsumsi ransum mengandung 5\% SKMK (R2) dan 5\% SKMK + 10\% TBSJM (R3) mempunyai kecernaan bahan organik, lemak kasar dan kandungan asam linoleat daging yang lebih tinggi $(\mathrm{P}<0,05)$ dibanding ransum kontrol (R1). Sapi Bali yang mengkonsumsi ransum R1 dan R2 mempunyai kecernaan protein kasar yang lebih tinggi $(P<0,05)$ dibanding R3. Disimpulkan bahwa suplementasi 5\% SKMK 10\% TBSJM dalam ransum meningkatkan kecernaan bahan organik, kecernaan lemak kasar dan kandungan asam lemak linoleat daging sapi Bali.

Kata kunci: sabun kalsium, pertumbuhan, kecernaan, metabolit darah, asam lemak daging, sapi Bali

${ }^{*}$ Corresponding author:

E-mail: kgwiryawan61@gmail.com 


\section{INTRODUCTION}

Bali cattle is one of the leading animal protein commodities in supplying national and export demands of meat. To ensure a maximum meat production of Bali cattle, fattening is an important stage in industry that needs to be improved (Tahuk \& Dethan, 2010). However, farmers rarely concerned with cattle feed quality despite that this factor serves as one of the main factors in determining a successful fattening process. As a result, the animal growth was not optimal indicated by the low weight gain and poor feed conversion ratio.

The high proportion of energy needed by ruminant animals is the reason to explore alternative feed ingredients with high energy density. There are several sources of feed ingredients containing high energy density, e.g. vegetable oils and agricultural waste products. The use of vegetable oils in ruminants is promising due to their high energy densities and better qualities of unsaturated fatty acids. On the other hand, the agricultural waste has its own advantages which are large in quantity, containing high nutrient materials and low cost. One of agricultural wastes that have the potential to be used as an animal feed is cashew fruit. It has good nutritional value (based on the percentage of dry matter) i.e.: $12.68 \%$ $14.42 \%$ crude protein; $5.22 \%-10.05 \%$ crude fiber; $22.80 \%$ $52.82 \%$ total sugar in fresh or sun-dried cashew fruit (Adebowale et al., 2011). However, cashew fruits contain high amount of non-extractable condensed tannins of $52 \mathrm{~g} / \mathrm{kg}$ dry matter (Rufino et al., 2010). Aguerre et al. (2016) reported that tannins can reduce the amount of protein that can be digested in the rumen and increase the flow of protein to the small intestine. In relation to the biohydrogenation of fatty acids (FAs) in the rumen, tannins were reported to be responsible in reducing polyunsaturated fatty acids (PUFA) biohydrogenation, accumulating t11 C18:1 (vaccenic acid) and/or decreasing the concentration of C18:0 (stearic acid) (KhiaosaArd et al., 2009).

Fat or fatty acid is a high density energy source. It produces higher energy than carbohydrate or protein (Wina et al., 2014). Supplementation of unsaturated fatty acids does not only provide energy, but also increases the production and quality of ruminants' meat (Ludden et al., 2009). However, the use of oil or fat with high unsaturated fatty acids in cattle needs to be controlled to ensure that it does not interfere with the ruminants' digestion system.

Efficient fat use in ruminant livestock is highly dependent on fat transformation pattern in the rumen i.e. lipolysis and biohydrogenation process by rumen microorganisms (Lourenco et al., 2010). Maia et al. (2010) reported that unsaturated fatty acids could be toxic to rumen due to its ability to inhibit cell integrity and microbes growth, and therefore disrupt feed fermentation process, especially feed fiber fermentation. If the fat biohydrogenation process can be controlled, It is possible to modify the fatty acid composition of beef meat toward a healthier profile by including heat-treated oilseeds in the ration to control the degree of lipid metabolism in the rumen (McNiven et al., 2011)
Efforts to increase the benefits and decrease the negative effects of unsaturated fatty acids in ruminant livestock can be done by protecting unsaturated fatty acids from giving negative effects on rumen digestive process. Jenkins \& Bridges (2007) reported that several types of technology to protect unsaturated fatty acids have been published in great details such as: formaldehyde treated fats, calcium salts and fatty acid amides. Technology in the form of calcium soaps used to protect unsaturated fatty acids is the most widely used. Currently, there are several calcium salt products commercially available for enhancing the supply of unsaturated fatty acids in cattle's meat. The previous in vitro study conducted by the authors indicated that the supplementation of $5 \%$ soybean oil calcium soap + $10 \%$ cashew apple flour had no negative impacts on the fermentation characteristics, microorganism populations and digestibilities of dry matter and organic matter in Bali cattle.

Based on the above reason, this study was conducted to evaluate the effectiveness of soybean oil calcium soaps (SOCS) supplementation and cashew fruit flour (CFF) utilization on the growth performance, nutrients digestibility, blood metabolite profile and fatty acid content in Bali cattle's meat.

\section{MATERIALS AND METHODS}

\section{Materials}

Twelve male Bali cattle aged \pm 2 years old with average body weight of $222 \pm 13.55 \mathrm{~kg}$ and variation coefficient of $6.10 \%$ were used in this research. The research rations were $40 \%$ of native grass and $60 \%$ of concentrate. The concentrate consisted of coconut meal, cassava, pollard, cashew fruit flour, molasses, soybean oil calcium soaps, $\mathrm{CaCO}_{3^{\prime}}$ urea, and beef cattle premix. Calcium soap materials consisted of soybean oil produced by Mazola, $\mathrm{NaOH}, \mathrm{KOH}$, distilled water, and technical $\mathrm{CaCl}_{2}$.

Equipment and materials for blood and urea space analyses consisted of syringes $(10 \mathrm{~mL}$ and $20 \mathrm{~mL})$, heparinized blood tubes, $20 \%$ physiological urea solution, KIT analysis for cholesterol, triglycerides, low density lipoprotein (LDL), and high density lipoprotein (HDL).

\section{Design, Procedure, and Variables}

The research used a randomized complete block design with 3 treatments and 4 blocks; R1 (ration containing $40 \%$ native grass $+60 \%$ concentrate without soybean oil calcium soap and cashew fruit flour), R2 (ration containing $40 \%$ native grass $+60 \%$ concentrate supplemented with 5\% SOCS), R3 (ration containing $40 \%$ native grass $+60 \%$ concentrate supplemented with $5 \%$ SOCS and 10\% CFF). The grass used in this research was a wild grass that grows freely on open fields within the Bogor Agricultural Agricultural. Ration contained TDN $75 \%$, CP $15 \%$, and ether extract $2.9 \%-4 \%$ to meet nutrient requirement of cattle (Kearl, 1982) (Table 1). The contents of total fat, total fatty acid, saturated fatty 
acid, and unsaturated fatty acid of treatment ration (\% dry matter) are presented in Table 2.

The production of soybean oil calcium soap was started with saponification of soybean oil following the procedure suggested by Apriyantono et al. (1989) to determine the volume of the needed $\mathrm{NaOH}$ liquid. The procedure to make calcium soap was conducted by heating a mixed liquid of $\mathrm{NaOH}$ and soybean oil using a hotplate (set at $180^{\circ} \mathrm{C}$ ) and stirred at $800 \mathrm{rpm}$ until the $\mathrm{NaOH}$ and soybean oil were perfectly dissolved. Some $\mathrm{CaCl}_{2}$ liquid $\left(2.35 \mathrm{~g}\right.$ crystal $\mathrm{CaCl}_{2}$ and $4.7 \mathrm{~mL}$ of distilled water) was added in the mixture and stirred slowly to produce soybean oil calcium soap (Kumar et al., 2006)

The research treatment was started by adapting Bali cattle with the stall and its ration for $14 \mathrm{~d}$, until they consumed their ration in a constant amount. Before the cattle were treated with the rations, they were weighed to determine their initial weight and then repeated every month for four months. The ration treatment was given on $2.5 \%$ of the cattle individual body weight (based on dry matter) twice a day at 8 a.m. and 4 p.m. Native grass was also given twice a day, at 9 a.m. and 5 p.m., after the cattle consumed their concentrate. Clean drinking water was given ad libitium. Residual of native grass and concentrate was calculated every morning before providing a new ration.

Calculation of the feed nutritional value was conducted by taking $\pm 500 \mathrm{~g}$ of the provided native grass sample and the residual every week from each cattle's ration during the research period. Concentrate samples were taken every time the concentrate were made (once

Table 1. The ingredient and nutrient composition of experimental diets

\begin{tabular}{lrrr}
\hline \multirow{2}{*}{ Variables } & \multicolumn{3}{c}{ Diets \% of DM } \\
\cline { 2 - 4 } & \multicolumn{1}{c}{$\mathrm{R} 1$} & $\mathrm{R} 2$ & $\mathrm{R} 3$ \\
\hline Ingredients (\%): & 40.00 & 40.00 & 40.00 \\
$\quad$ Native grass & 60.00 & 60.00 & 60.00 \\
Concentrate (\%) : & 30.00 & 25.00 & 23.00 \\
$\quad$ Tapioca waste & 31.00 & 31.00 & 25.50 \\
Pollard & 20.50 & 20.50 & 18.00 \\
Coconut meal & - & - & 10.00 \\
Cashew fruit flour & 15.00 & 15.00 & 15.00 \\
Molasses & 1.50 & 1.50 & 1.50 \\
CaCO ${ }_{3}$ & 1.50 & 1.50 & 1.50 \\
Urea & - & 5.00 & 5.00 \\
Soybean oil calcium soap & 0.50 & 0.50 & 0.50 \\
$\quad$ Premix super cattle & & & \\
Nutrient composition ${ }^{*}$ : & 68.63 & 68.65 & 68.56 \\
$\quad$ Total digestible nutrient & 13.09 & 13.08 & 12.87 \\
Crude protein & 3.79 & 6.18 & 6.24 \\
\hline Ether extract & &
\end{tabular}

Note: $\mathrm{R} 1=40 \%$ native grass $(\mathrm{NG})+60 \%$ concentrate, $\mathrm{R} 2=40 \% \mathrm{NG}+$ $60 \%$ concentrate supplemented with $5 \%$ soybean oil calcium soap (SOCS), and R3= $(40 \% \mathrm{NG}+60 \%$ concentrate supplemented with $5 \%$ SOCS $+10 \%$ cashew fruit flour (CFF). ${ }^{*}$ ) Estimation from Standar Tables of Feed Composition for ruminants in Indonesia. in 2 weeks). Later, proximate analyses were carried out to determine the chemical compositions of the given native grass and concentrate.

Research variables observed consisted of (i) growth performance (feed intake, daily body weight gain, and feed efficiency and (ii) nutrient digestibility consisted of dry matter, organic matter, crude protein, ether extract, crude fiber, neutral detergent fiber, and acid detergent fiber. Blood metabolite profiles consisted of cholesterol, triglycerides, LDL, and HDL. The measured Bali meat quality parameters were total, saturated and unsaturated fatty acids content.

Digestibility of the ration was calculated by collecting feces and urine daily for eight days at the end of the research period. Feces and urine samples were collected as much as $10 \%$ of the total excreted to be analyzed in the Laboratory of Dairy Animal Nutrition, Department of Nutrition and Feed Technology, Bogor Agricultural University.

Blood samples were taken after $60 \mathrm{~d}$ of the treatment to measure blood metabolite concentration. Blood samples of each cattle were taken in the morning before feeding through jugular vein, using $10 \mathrm{~mL}$ vacutainer, placed in a tube containing EDTA, and kept in a cool box to prevent blood clotting before being analyzed in the laboratory. The cholesterol, triglyceride, LDL, and HDL were analyzed using KIT manufactured in Germany for PT Rajawali Nusindo, i.e. Cat. No. 101592 for cholesterol, Cat. No. 116392 for triglyceride and Cat. No. 108491 for HDL.

Meat fatty acid profile was measured by slaughtering the cattle at the end of the research period. Collected meat samples were extracted from the longissimus dorsal muscle. Fat and fatty acid contents of the samples were analyzed using Folch-Gravimetric methods following by AOAC (2005).

All research procedures had been approved by the animal ethic committee, Bogor Agricultural University No.08-2015 IPB.

Table 2. The content of total fat, total fatty acid, saturated fatty acid, and unsaturated fatty acid of treatment ration $(\%$ dry matter $)^{*}$

\begin{tabular}{lrrr}
\hline \multirow{2}{*}{ Variables } & \multicolumn{3}{c}{ Treatments } \\
\cline { 2 - 4 } \multicolumn{1}{c}{ R1 } & \multicolumn{1}{c}{ R2 } & \multicolumn{1}{c}{ R3 } \\
\hline Total fat & 2.90 & 4.01 & 4.03 \\
Total fatty acid & 51.38 & 53.93 & 52.66 \\
Saturated fatty acid & 27.82 & 19.17 & 18.17 \\
Palmitic & 20.58 & 19.20 & 20.86 \\
Stearic & 1.55 & 1.89 & 1.85 \\
Unsaturated fatty acid & 23.56 & 34.76 & 34.19 \\
$\quad$ Oleic & 6.30 & 9.17 & 9.33 \\
$\quad$ Linoleic & 10.20 & 20.05 & 19.29 \\
$\quad$ Linolenic & 1.85 & 3.15 & 2.18 \\
\hline
\end{tabular}

Note: *) Analysis result by IPB Integrated Laboratory. R1 $=40 \%$ native grass $(\mathrm{NG})+60 \%$ concentrate, $\mathrm{R} 2=40 \% \mathrm{NG}+60 \%$ concentrate supplemented with $5 \%$ soybean oil calcium soap (SOCS), and R3= $(40 \% \mathrm{NG}+60 \%$ concentrate supplemented with $5 \%$ SOCS $+10 \%$ cashew fruit flour (CFF). 


\section{Data Analysis}

The data were analyzed using Analysis of Variance (ANOVA) by means of Statistical Package for the Social Sciences (IBM ${ }^{\circledR}$ SPSS ${ }^{\circledR}$ version 21.0., 2012). Duncan Multiple Range Test (DMRT) was applied to determine the differences among treatments. Differences were considered significant at $\mathrm{P}<0.05$. and $\mathrm{P}<0.01$.

\section{RESULTS}

\section{Animal Performance}

The supplementation of 5\% SOCS (R2) and 5\% SOCS $+10 \%$ CFF (R3) treatments did not significantly affect the dry matter, organic matter intake, feed efficiency, and the average daily body weight gain of Bali cattle (Table 3). The data also showed that the average dry matter and organic matter intakes of native grass and concentrate were not different between the treatments.

\section{Nutrient Digestibility}

Different treatment rations did not have significant effect on dry matter digestibility (DMD), however sig- nificantly affect $(\mathrm{P}<0.05)$ on the digestibility of organic matter (OMD) and ether extract (EE). The crude protein digestibility in Bali cattle fed with control (R1) and ration supplemented with 5\% SOCS (R2) was higher than the ones fed with ration supplemented with 5\% SOCS $+10 \%$ CFF (R3); but there was no difference of crude protein digestibility between cattle treated with control and 5\% SOCS. The supplementation of 5\% SOCS and 5\% SOCS $+10 \%$ CFF in ration did not affect the digestibility of crude fiber (CF), acid detergent fiber (ADF) and neutral detergent fiber (NDF) in Bali cattle (Table 4).

The data showed that the Bali cattle fed with ration supplemented with 5\% SOCS and 5\% SOCS $+10 \%$ CFF did not have significant difference in DMD compared to those fed with control. The averages of OMD and EE of ration supplemented with 5\% SOCS and 5\% SOCS + $10 \%$ CFF were significantly higher $(\mathrm{P}<0.05)$ compared to those of the control ration. However, there was no significant difference between the averages of OMD and EE between Bali cattle fed with ration supplemented with $5 \%$ SOCS and $5 \%$ SOCS $+10 \%$ CFF.

\section{Blood Metabolite}

Supplementation of 5\% SOCS and 5\% SOCS $+10 \%$ CFF did not have significant effect on the cholesterol,

Table 3. The average of dry matter and organic matter intake (\% dry matter), daily weight gain and feed efficiency of Bali cattle

\begin{tabular}{lcccc}
\hline \multirow{2}{*}{ Variables } & \multicolumn{2}{c}{ Treatments } & R & P value \\
\cline { 2 - 4 } & R1 & R2 & $5.20 \pm 0.19$ & 0.25 \\
Total dry matter intake (kg/day) & $4.77 \pm 0.65$ & $4.96 \pm 0.41$ & $1.88 \pm 0.24$ & 0.27 \\
Native grass dry matter intake (kg/day) & $1.65 \pm 0.28$ & $1.51 \pm 0.28$ & $3.32 \pm 0.42$ & 0.42 \\
Concentrate dry matter intake (kg/day) & $3.12 \pm 0.42$ & $3.44 \pm 0.16$ & $4.67 \pm 0.19$ & 0.61 \\
Total organic matter intake (kg/day) & $4.33 \pm 0.59$ & $4.49 \pm 0.37$ & $1.69 \pm 0.22$ & 0.27 \\
Native grass organic matter intake (kg/day) & $1.49 \pm 0.26$ & $1.37 \pm 0.26$ & $2.98 \pm 0.38$ & 0.44 \\
Concentrate organic matter intake (kg/day) & $2.84 \pm 0.38$ & $3.13 \pm 0.15$ & $0.92 \pm 0.16$ & 0.24 \\
Daily body weight gain (kg/head/day) & $0.65 \pm 0.19$ & $0.81 \pm 0.17$ & $0.18 \pm 0.03$ & 0.19 \\
Feed efficiency (DBWG/DMI) & $0.13 \pm 0.03$ & $0.16 \pm 0.02$ & & \\
\hline
\end{tabular}

Note: $\mathrm{DMI}=$ dry matter intake, $\mathrm{DBWG}=$ daily body weight gain. R1 $=40 \%$ native grass $(\mathrm{NG})+60 \%$ concentrate, $\mathrm{R} 2=40 \% \mathrm{NG}+60 \%$ concentrate supplemented with $5 \%$ soybean oil calcium soap (SOCS), and R3= $(40 \%$ NG $+60 \%$ concentrate supplemented with $5 \%$ SOCS $+10 \%$ cashew fruit flour $(\mathrm{CFF})$.

Table 4. The average digestibility of nutrients of Bali cattle fed different ration (\%)

\begin{tabular}{lcccc}
\hline \multicolumn{1}{c}{ Variables } & \multicolumn{3}{c}{ Treatments } & \multirow{2}{*}{ P value } \\
\cline { 2 - 4 } & R1 & R2 & R3 & 0.07 \\
Dry matter & $61.08 \pm 2.34$ & $65.49 \pm 2.39$ & $65.16 \pm 2.47$ & 0.04 \\
Organic matter & $64.54 \pm 2.06^{\mathrm{a}}$ & $69.82 \pm 2.58^{\mathrm{b}}$ & $68.36 \pm 2.28^{\mathrm{b}}$ & 0.05 \\
Crude protein & $75.10 \pm 0.31^{\mathrm{a}}$ & $76.32 \pm 0.31^{\mathrm{a}}$ & $72.89 \pm 1.88^{\mathrm{b}}$ & 0.03 \\
Ether extract & $87.51 \pm 2.09^{\mathrm{a}}$ & $94.30 \pm 1.29^{\mathrm{b}}$ & $93.93 \pm 0.50^{\mathrm{bc}}$ & 0.20 \\
Crude fiber & $49.53 \pm 3.45$ & $54.51 \pm 1.27$ & $48.55 \pm 7.65$ & 0.59 \\
Acid detergent fiber & $49.05 \pm 3.68$ & $48.91 \pm 3.26$ & $45.64 \pm 5.70$ & 0.84 \\
Neutral detergent fiber & $52.18 \pm 4.67$ & $51.96 \pm 1.36$ & $52.05 \pm 3.97$ & \\
\hline
\end{tabular}

Note: Means in the same row with different superscripts differ significantly $(\mathrm{P}<0.05)$. R1 $=40 \%$ native grass $(\mathrm{NG})+60 \%$ concentrate, R2 $=40 \% \mathrm{NG}+60 \%$ concentrate supplemented with $5 \%$ soybean oil calcium soap (SOCS), and R3 $=(40 \% \mathrm{NG}+60 \%$ concentrate supplemented with $5 \%$ SOCS $+10 \%$ cashew fruit flour (CFF). 
Table 5. The average of blood metabolite profile of Bali cattle $(\mathrm{mg} / \mathrm{dl})$

\begin{tabular}{lrrrr}
\hline \multirow{2}{*}{ Variables } & \multicolumn{1}{c}{ Treatments } & \multirow{2}{*}{ P value } \\
\cline { 2 - 4 } & \multicolumn{1}{c}{ R1 } & \multicolumn{1}{c}{ R2 } & R3 & 0.46 \\
Cholesterol & $81.59 \pm 19.26$ & $100.00 \pm 28.44$ & $96.81 \pm 14.43$ & 0.91 \\
Triglyceryde & $28.99 \pm 9.62$ & $25.49 \pm 9.75$ & $25.97 \pm 11.66$ & 0.72 \\
Low density lipoprotein (LDL) & $46.71 \pm 15.09$ & $56.00 \pm 24.07$ & $55.76 \pm 12.65$ & 0.37 \\
High density lipoprotein (HDL) & $29.19 \pm 10.03$ & $38.91 \pm 13.94$ & $36.18 \pm 6.75$ & \\
\hline
\end{tabular}

Note: $\mathrm{R} 1=40 \%$ native grass $(\mathrm{NG})+60 \%$ concentrate, $\mathrm{R} 2=40 \% \mathrm{NG}+60 \%$ concentrate supplemented with $5 \%$ soybean oil calcium soap (SOCS), and R3= $(40 \% \mathrm{NG}+60 \%$ concentrate supplemented with $5 \%$ SOCS $+10 \%$ cashew fruit flour (CFF).

Table 6. The average of fatty acids profile of Bali cattle meat (\%)

\begin{tabular}{lrrrr}
\hline \multicolumn{1}{c}{ Variables } & \multicolumn{3}{c}{ Treatments } & P value \\
\cline { 2 - 4 } & \multicolumn{1}{c}{ R1 } & R2 & R3 & 0.59 \\
Total fatty acid & $64.80 \pm 0.03$ & $61.82 \pm 8.44$ & $64.87 \pm 5.81$ & 0.98 \\
Saturated fatty acid & $60.69 \pm 0.23$ & $61.61 \pm 3.95$ & $61.90 \pm 1.79$ & 0.39 \\
Palmitic & $2.29 \pm 1.35$ & $1.87 \pm 0.41$ & $2.07 \pm 0.53$ & 0.92 \\
Stearic & $14.22 \pm 8.34$ & $14.32 \pm 2.62$ & $14.65 \pm 1.25$ & 0.98 \\
Unsaturated fatty acid & $39.37 \pm 0.23$ & $38.39 \pm 3.94$ & $38.11 \pm 1.75$ & 0.43 \\
Oleic & $18.61 \pm 0.28$ & $16.22 \pm 2.88$ & $17.93 \pm 3.82$ & 0.09 \\
Linoleic & $1.95 \pm 0.51^{\mathrm{a}}$ & $2.83 \pm 0.88^{\mathrm{b}}$ & $2.36 \pm 0.54^{\mathrm{b}}$ & \\
\hline
\end{tabular}

Note: Means in the same row with different superscripts differ significantly $(\mathrm{P}<0.05)$. R $1=40 \%$ native grass $(\mathrm{NG})+60 \%$ concentrate, $\mathrm{R} 2=40 \% \mathrm{NG}+60 \%$ concentrate supplemented with $5 \%$ soybean oil calcium soap (SOCS), and R3 $=(40 \% \mathrm{NG}+60 \%$ concentrate supplemented with $5 \% \mathrm{SOCS}+10 \%$ cashew fruit flour (CFF).

triglycerides, low density lipoprotein (LDL) and high density lipoprotein (HDL) levels in the blood of Bali cattle (Table 5).

\section{Meat Fatty Acids Composition}

The supplementation of 5\% SOCS and 5\% SOCS + $10 \%$ CFF did not have significant effect on the total fat content, saturated and unsaturated fatty acids composition in Bali cattle's meat (Table 6). The level of palmitic, stearic, oleic and linolenic acids of Bali cattle meat were not different among the treatments, but the meat's linoleic acids contents of 5\% SOCS and 5\% SOCS $+10 \%$ CFF treatments were higher than that of control.

\section{DISCUSSION}

\section{Animal Performance}

Fat is often added to rations to increase the dietary energy density and total energy intake. The supplementation of soybean oil calcium soap and cashew fruit flour in ration did not increase the intake of dry matter, organic matter, feed efficiency, and daily body weight gain of Bali cattle. This confirms the report of Salinas et al. (2006) where fat calcium soap in different levels cannot increase the dry matter intake, daily body weight gain and feed efficiency on goats. The addition of $5 \%$ SOCS in ration which did not affect the intake of dry matter and organic matter of Bali cattle was expected due to the high substance of fat in SOCS (6.18\%) and SOCS + CFF
(6.24\%) rations. The high level of energy density and the energy consumed had caused the cattle to restrict the intake of ration to catch the homeostatic energy within its body.

The influence of supplementation of 5\% SOCS in $\mathrm{R} 2$ ration and 5\% SOCS $+10 \%$ CFF in $\mathrm{R} 3$ resulting in the similar performance of the cattle's intake of dry matter, daily weight gain, and feed efficiency compared to the control (R1) indicates one important point. That is the calcium soap product is clearly able to depress the toxicity of high unsaturated fat acid in soy bean oil on the growth of microbe and fermentation within the rumen. This was shown by the digestibility of dry matter and fiber fraction (crude fiber, ADF, and NDF) which were not different between all treated rations (R2, R3, and control). Fiorentini et al. (2015) reported the rations with some types of protection could decreased the effects of lipid in ruminal. It confirms the research by Manso et al. (2006) who reported that the inclusion of palm oil fatty acids as calcium soaps in the ration was able to reduce the negative effects of the addition of $41 \mathrm{~g}$ of palm oil $/ \mathrm{kg}$ on fiber digestibility.

The digestibility of organic matter and EE in SOCS and SOCS + CFF treatments were higher than that of control. These were the indicators that the supplementation of $5 \%$ SOCS (R2) and 5\% SOCS $+10 \%$ CFF (R3) could increase the density and the total energy intake and thus ensure sufficient energy flow absorbed within the rumen to fulfill the energy needed by the treated Bali cattle. The high density of energy consumed in R2 and $\mathrm{R} 3$ rations might come from the addition of $5 \%$ 
SOCS and $10 \%$ CFF. This is based on the general theory that the addition of lipid in ruminant rations is intended to increase energy density, improve livestock system efficiency and generate better meat quality for improving human health (Fiorentini et al., 2015). In addition, the high EE digestibility for R3 was probably caused by the influence of tannins contained in the $10 \%$ CFF which played a role in depressing the process of biohydrogenation of PUFA in the rumen (Khiaosa-Ard et al., 2009). The high digestibility of SOCS and SOCS + CFF rations will increase the amount of energy absorbed and used by the cattle.

An interesting finding in this research was that the supplementation of 5\% SOCS (R2) and 5\% SOCS + 10\% CFF (R3) resulted better daily weight gains of Bali cattle $(0.81 \pm 0.17 \mathrm{~kg} / \mathrm{head} /$ day for R2 and $0.92 \pm 0.16 \mathrm{~kg} / \mathrm{head} /$ day for R3). These results were higher compared to the daily weight gains of Bali cattle reported by Tahuk \& Dethan (2010), i.e. $0.53 \mathrm{~kg} / \mathrm{head} / \mathrm{day}$. The average values of ADG in Bali cattle fed with SOCS and SOCS + CFF were not different than that of control $(0.65 \pm 0.19) \mathrm{kg} / \mathrm{head} /$ day. This result was likely caused by the insufficient number of cattle as replication in this study.

\section{Nutrient Digestibility}

The supplementation of 5\% SOCS in R2 ration and $5 \%$ SOCS $+10 \%$ CFF in $\mathrm{R} 3$ ration did not produce significant difference in DDM compared to the control (R1) (Table 4). The research findings showed that the use of $5 \%$ SOCS and $5 \%$ SOCS $+10 \%$ CFF resulted in higher OMD compared to control. In addition, the average values of OMD of Bali cattle fed with SOCS ration were not significantly different from SOCS + CFF ration. However, the high level of OMD averages of cattle treated with SOCS and SOCS + CFF ration compared to cattle treated with control might suggested that the addition of $5 \%$ of calcium soap has increased the ether extract (EE) digestibility. This is inline with Voigt et al. (2006) who stated that the digestibility of organic matter was higher for ration with Ca-PFA (fat supplement contained the highest proportion of unsaturated FA) than for rations with hydrogenated triacylglyceride from palm oil and fractionated triacylglyceride from palm oil because of the increased digestibility of EE.

The high digestibility of EE in SOCS ration (94.32\%) and SOCS + CFF ration $(93.93 \%)$ was suspected as an implication of the addition of $5 \%$ SOCS which could increase the flow of fatty acid in the post ruminal digestion. This could be linked to calcium soaps' role which was protecting unsaturated fatty acids in soybean oil from hydrolysis and hydrogenation of rumen microbes. Voigt et al. (2006) argued that the rumen-protected fats have to be highly digestible in the post-ruminal tract. Manso et al. (2006) reported that the EE digestibility increases because the added fat is characterized by a greater digestibility and availability within food particles than the fatty acids. The increase in the flow and digestibility of fat or fatty acid would increase the amount of energy digested and absorbed in the system of the cattle's body.
The data showed that supplementation of calcium oil and cashew fruit flour could significantly influence $(\mathrm{P}<0.05)$ the digestibility of crude protein. The supplementation of $5 \%$ SOCS $+10 \%$ CFF in $\mathrm{R} 3$ ration resulted the lowest digestibility of $\mathrm{CP}(\mathrm{P}<0.05)$ compared to control and supplementation of 5\% SOCS. The low digestibility of crude protein in Bali cattle fed with SOCS + CFF ration was possibly caused by the influence of tannin substances in the cashew fruit flour. The substances cause the degradation of digestibility of crude protein in the rations. Tannins can form complexes with protein and carbohydrate substances (Jayanegara et al., 2009). Bunglavan \& Dutta (2013) reported that these complexes are stable at normal rumen $\mathrm{pH}$, but it dissociates when $\mathrm{pH}$ falls below 3.5 (such as in the abomasum, $\mathrm{pH}$ 2.5-3) or rises above $\mathrm{pH} 8$ (for example in the duodenum, $\mathrm{pH}$ 8). The strong bond of tannin complexes with the two substances caused the digestibility of protein substance and fraction of carbohydrate substances decrease in the digestion process (Jayanegara \& Palupi, 2010). Even though the existence of tannin can reduce protein digestibility in rumen, the complex bonds of tanninprotein give a benefit towards the increase in protein flow in the post rumen digestion (Aguerre et al., 2016). Similar result reported by Wina et al. (2012) who stated that even though tannin compounds can decrease the crude protein digestibility, they are actually useful in increasing protein by-pass flow which is required for cattle's growth. Digestibility of control and SOCS crude protein indicated that the use of $5 \%$ SOCS did not have negative effect on the digestibility of crude protein.

The supplementation of 5\% SOCS and 10\% CFF in this research did not influence the chemical condition within the rumen ecosystem. It was shown by the average values of $\mathrm{pH}, \mathrm{NH}_{3}-\mathrm{N}$ and total VFA on the whole treatments which were still in normal ranges $(\mathrm{pH}$ of $\mathrm{R} 1=$ $6.20, \mathrm{R} 2=6.30, \mathrm{R} 3=6.30 ; \mathrm{NH}_{3}-\mathrm{N}$ concentration of $\mathrm{R} 1=8.35$ $\mathrm{mM}, \mathrm{R} 2=7.02 \mathrm{mM}, \mathrm{R} 3=9.30 \mathrm{mM}$; and total VFA production of $\mathrm{R} 1=89.75 \mathrm{mM}, \mathrm{R} 2=82.94 \mathrm{mM}, \mathrm{R} 3=88.95 \mathrm{mM})$. The different treatments which resulted in $\mathrm{pH}$ level ranged between 6.20 and 6.30 , indicating that ration fermentation was still in normal state. Hungate (1988) reported that the rate of fermentation within the rumen can be obtained during this process and later at $39{ }^{\circ} \mathrm{C}$ and at a $\mathrm{pH}$ of 6.0-7.0.

The average variable values of rumen fermentation were in normal range which indicated that the supplementation of $5 \%$ SOCS and $10 \%$ CFF in the rations did not give significant negative effect on the digestion process in the rumen. Voigt et al. (2006) reported that calcium salts of long-chain fatty acid are insoluble at ruminal $\mathrm{pH}$ of higher than 6.0 and thus, have little effect on microbial fermentation This result was in accordance with Hidayah et al. (2014) who reported that the inclusion of different levels of sesame calcium soap, canola and flaxseed oils did not affect the $\mathrm{pH}$ level, ammonia and total VFA production of an incubated rumen. The role of calcium soaps supplementation to depress the negative effects of unsaturated fatty acids in the rumen ecosystem was possible due to a stable bonding of ionic calcium (Ca) and unsaturated fatty acids in the soap 
product which was insoluble in the rumen $\mathrm{pH}$ condition (neutral $\mathrm{pH}$ ). It was might due to the non significant different in digestibility of DMD, CF, ADF, and NDF of all treatments.

\section{Blood Metabolite}

In the present work, the effects of CSFA supplementation on several blood parameters i.e. triglycerides, low density lipoprotein (LDL) and high density lipoprotein (HDL) in Bali cattle is presented in Table 5. Results of the research showed that the supplementation of $5 \%$ SOCS and 10\% CFF in R2 and R3 rations did not give significant effect on the levels of cholesterol, triglycerides, LDL and HDL of Bali cattle. This result is different from the report of El-Nour et al. (2012) who stated that the effects of fat supplementation in ewes feed resulted in the increased plasma concentrations of cholesterol, triglycerides, high-density lipoprotein cholesterol (HDL-C), low-density lipoprotein cholesterol (LDL-C), and progesterone.

The supplementation of $5 \%$ SOCS and $10 \%$ CFF had not yet resulted in significant change towards all parameters of blood metabolite of Bali cattle. This was likely caused by the amount of soybean oil calcium soap and cashew fruit flour supplemented in the rations did not contribute sufficient nutrient towards the synthesis of cholesterol within the cattle's body. Dietary cholesterol or "exogenous" cholesterol accounts for approximately one-third of pooled body cholesterol, and the remaining $70 \%$ is synthesized in the body (endogenous cholesterol). Exogenous cholesterol from food could significantly influence the amount of production and the formation of endogenous cholesterol. Both "endogenous" and "exogenous" cholesterol are transferred by a number of lipoprotein particles including chylomicrons, VLDL, LDL and HDL (Kapourchali et al., 2016).

There were no significant differences in the level of cholesterol between treatments in the treated cattle. This was possibly the result of the use of $5 \%$ SOCS as one of the ration ingredients which contains high PUFA responsible in depressing the cholesterol synthesis within the body of Bali cattle. Ramprasath et al. (2012) reported that plasma cholesterol concentrations decreased with the consumption of high PUFA and increased with high saturated fatty acid (SFA) rations. This served as an indicator that PUFA contained in the soybean calcium soap was likely able to depress cholesterol synthesis within the body of Bali cattle that consumed both rations (R2 and R3). The absence of cholesterol increase in blood plasma of cattle treated with SOCS (R2) and SOCS + CFF (R3) rations had subsequently implicated that the level of triglyceride and LDL in the cattle treated with R2 and R3 rations were also not different with cattle treated with control.

The suppression in the absorption and synthesis of cholesterol subsequently has implications towards the level of triglycerides and LDL in SOCS + CFF treatment might be also contributed by the tannin substances contained in the $10 \% \mathrm{CFF}$ which influences the process of biohydrogenation of fat in the rumen. In relation to biohydrogenation of FA in the rumen, tannin played a role in reducing PUFA biohydrogenation, accumulating $\mathrm{t} 11 \mathrm{C} 18: 1$ (vaccenic acid) and/or decreasing the concentration of C18:0 (stearic acid) (Khiaosa-Ard et al., 2009). Such phenomenon can be linked to the toxicity of tannin phenolic towards bacteria species involved within the process of biohydrogenation of fatty acid (Khiaosa-Ard et al., 2009). It is also possible that phenolics may inhibit the process of lipolysis which is a precondition prior to further transformation of fatty acids, i.e. biohydrogenation (Lourenco et al., 2010).

\section{Meat Fatty Acid Composition}

The feed supplementation of SOCS and SOCS + $\mathrm{CFF}$ in the rations did not produce significant differences in the cattle's profile of fatty acids (total fatty acids, unsaturated and saturated fatty acids), except the linoleic acid content (Table 6). The supplementation of $5 \%$ SOCS in R2 ration and 5\% SOCS $+10 \%$ CFF in R3 ration tended to produce higher linoleic acid substance in the meat of Bali cattle compared to R1 ration (control).

The supplementation of 5\% SOCS and 10\% CFF had not yet able to improve the composition of total fatty acid and the ratio of PUFA/SFA in the meat of Bali cattle. This result was likely caused by a number of factors known to influence the composition of fatty acid in beef cattle. Smith et al. (2009) reported that several major factors influencing fatty acid composition in beef include the age of animal, ration composition, and breed type. Animal age and breed type specifically affect the concentration of mono unsaturated fatty acid (MUFA) in beef by affecting stearoyl-CoA desaturase (SCD) gene expression and activity, whereas ration is the sole source of the essential fatty acids, linoleic acid, and $\alpha$-linolenic acid.

The supplementation effect of 5\% SOCS and 10\% CFF towards the change of fat substance, total fatty acids, and the ratio of PUFA/SFA which were not significantly different from the control was suspected as the product imperfection of calcium soap and CFF tannins in protecting PUFA of soybean oil from biohydrogenation process in the rumen. Our results were in accordance with Fiorentini et al. (2015) who argued that there was a partial dissociation of calcium salts in soybean oil. Block et al. (2005) reported that the calcium salts of fatty acids could not completely inert in the rumen or as a "bypass" fat because calcium salts still dissociated into free calcium ions and free fatty acids. This was confirmed by Jenkins \& Bridges (2007) who stated that the long chain of unsaturated fatty acids e.g. linoleic and linoleic acids were difficult to be protected from rumen bacterial biohydrogenation processes compared to oleic fatty acid in the effort to increase the unsaturated fatty acids content in milk and "red" meat. The result of this research is in line with the report by da Luz e Silva et al. (2009) who stated that feeding CSFA increased ether extract percentage but had no effect on total of saturated, unsaturated, and saturated:unsaturated ratio. The relatively similar data of fat, fatty acid, and ratio of PUFA/ SFA in all treatments served as indications that the level of tannin phenolic substance in CFF was not optimal in 
preventing the process of biohydrogenation of PUFA in the rumen.

Our data showed that the contents of palmitic acid, stearic acid and oleic acid in the Bali cattle treated with control (R1), 5\% SOCS (R2), and 5\% SOCS $+10 \%$ CFF (R3) rations were not significantly different, but the linoleic acid content in Bali cattle's meat fed R2 and R3 tended to be higher than control. The result of this research is in agreement with the research done by (da Luz e Silva et al. (2009)) where CSFA increased conjugated linoleic acid (CLA) isomer C18:2 c9, t11 ( P<0.0001), total CLA $(\mathrm{P}=0.0001)$, but had no effect on total $\mathrm{n}-6$ and total n-3 percentages and n-6:n-3 ratio. The higher level of $\mathrm{C} 18: 2 \mathrm{c} 9, \mathrm{t} 11$ could be due to the action of $\Delta 9$ desaturase under C18:1 t11 which was also increased in rations containing CSFA. According to Silva et al. (2014), the endogenous synthesis of C18:2 c9, t11 CLA is the major source of CLA in body fat of ruminants.

The under achievement of the maximum effect of the soybean oil calcium soap supplementation to change unsaturated fatty acids profile in Bali cattle's meat may be attributed to the change of nutritional characteristic and the durability of unsaturated fatty acids calcium soap against the ecosystems dynamics and microbial biohydrogenation processes in the rumen. Block et al. (2005) suggested that the calcium salts durability against the rumen was influenced by the degree of unsaturation, $\mathrm{pH}$, and resident time in the rumen.

\section{CONCLUSION}

In conclusion supplementation of 5\% SOCS and $10 \%$ CFF in ration improved digestibility of organic matter, ether extract, and linoleic fatty acid content in meat of Bali cattle.

\section{ACKNOWLEDGEMENT}

The authors would like to thank Directorate General of Higher Education of Indonesia for BPPS scholarship and supporting this research through Funding Research Program-MP3EI.

\section{REFERENCES}

Adebowale B. A., O. Olubamiwa, \& M. A. K. Ogunjobi. 2011. Substitution value of sundried cashew apple bagasse in the diets of Clarias gariepinus. Int. Res. J. Agric.Sci. \& Soil Sci. 1: 268-272.

Aguerre M. J., M. C. Capozzolo, P. Lencioni, C. Cabral, \& M. A. Wattiaux. 2016. Effect of quebracho-chestnut tannin extracts at 2 dietary crude protein levels on performance, rumen fermentation, and nitrogen partitioning in dairy cows. J. Dairy Sci. 99: 1-11. https://doi.org/10.3168/jds.2015-10745

AOAC. 2005. Official Methods of Analysis 18 th. AOAC International, New York.

Apriyantono A., D. Fardiaz, N. L. Puspitasari, Sedarnawaty, \& S. Budiyanto. 1989. Analisis Pangan. IPB Press, Bogor (ID).

Block E., W. Chalupa, E. Evans, T. Jenkins, P. Moate, D. Palmquist, \& C. Sniffen. 2005. Calcium salts are highly digestible. Feedstuffs. 77: 1-7.

Bunglavan S. J. \& N. Dutta. 2013. Use of tannins as organic protectants of proteins in digestion of ruminants. Livest. Sci. 4: 67-77. da Luz e Silva S., P. R. Leme, S. M. Putrino, A. S. C. Pereira, A. C. Valinote, J. C. M. Nogueira Filho, \& D. P. D. Lanna. 2009. Fatty acid composition of intramuscular fat from Nellore steers fed dry or high moisture corn and calcium salts of fatty acids. Livest. Sci. 122: 290-295. https://doi. org/10.1016/j.livsci.2008.09.013

El-Nour H. H., S. M. Nasr, \& W. R. Hassan. 2012. Effect of calcium soap of fatty acids supplementation on serum biochemical parameters and ovarian activity during out-ofthe-breeding season in crossbred ewes. The Sci.World J. 2012: 1-7. https://doi.org/10.1100/2012/601840

Fiorentini G., I. P. C. Carvalho, J. D. Messana, R. C. Canesin, P. S. Castagnino, J. F. Lage, P. B. Arcuri, \& T. T. Berchielli. 2015. Effect of lipid sources with different fatty acid profiles on intake, nutrient digestion and ruminal fermentation of feedlot nellore steers. Asian Australas. J. Anim. Sci. 28: 1583-1591. https://doi.org/10.5713/ajas.15.0130

Hidayah, N., S. Suharti, \& K. G. Wiryawan. 2014. In vitro rumen fermentation of ration supplemented with protected vegetable oils. Med.Pet. 37: 129-135. https://doi.org/10.5398/ medpet.2014.37.2.129

Hungate, R. E. 1988. Introduction : The Ruminant and the Rumen. In: P. N. Hobson (ed.) The Rumen Microbial Ecosystem. Elsevier Applied Science, London and New York.

Jayanegara, A. \& E. Palupi. 2010. Condensed tannin effects on nitrogen digestion in ruminants: A meta-analysis from invitro and in vivo studies. Med.Pet. 33: 176-181. https://doi. org/10.5398/medpet.2010.33.3.176

Jenkins, T. C. \& W. C. Bridges. 2007. Protection of fatty acids against ruminal biohydrogenation in cattle. Eur. J. Lipid Sci. Technol. 109: 778-789. https://doi.org/10.1002/ ejlt.200700022

Kapourchali, F. R., G. Surendiran, A. Goulet, \& M. H. Moghadasian. 2016. The role of dietary cholesterol in lipoprotein metabolism and related metabolic abnormalities: A mini-review. Food Sci. Nut. 56: 1-32. https://doi.org/10.1 080/10408398.2013.842887

Kearl, C. L. 1982. Nutrient Requirements of Ruminants in Developing Countries, Utah State University, Utah (US).

Khiaosa-Ard R., S. F. Bryner, M. R. Scheeder, H. R. Wettstein, F. Leiber, M. Kreuzer, \& C. R. Soliva. 2009. Evidence for the inhibition of the terminal step of ruminal alpha-linolenic acid biohydrogenation by condensed tannins. J. Dairy Sci. 92: 177-188. https://doi.org/10.3168/jds.2008-1117

Kumar, R., K. Sivaiah, Y. R. Reddy, B. Ekambram, T. J. Reddy, \& G. V. N. Reddy. 2006. Effect of supplementation of dietary protected lipids on intake and nutrient utilization in Deccani lambs. Trop. Anim. Health Prod. 38: 151-158. https://doi.org/10.1007/s11250-006-4248-0

Lourenco, M., E. Ramos-Morales, \& R. J. Wallace. 2010. The role of microbes in rumen lipolysis and biohydrogenation and their manipulation The Animal Consortium. $\mathrm{p}$ 1008-1023.

Ludden, P. A., O. Kucuk, D. C. Rule, \& B. W. Hess. 2009. Growth and carcass fatty acid composition of beef steers fed soybean oil for increasing duration before slaughter. Meat Sci. 82: 185-92. https://doi.org/10.1016/j.meatsci.2009.01.009

Maia, M. R., L. C. Chaudhary, C. S. Bestwick, A. J. Richardson, N. McKain, T. R. Larson, I. A. Graham, \& R. J. Wallace. 2010. Toxicity of unsaturated fatty acids to the biohydrogenating ruminal bacterium, Butyrivibrio fibrisolvens. BMC Microbiol. 10: 52. https://doi.org/10.1186/1471-2180-10-52

Manso, T., T. Castro, A. R. Mantecón, \& V. Jimeno. 2006. Effects of palm oil and calcium soaps of palm oil fatty acids in fattening diets on digestibility, performance and chemical body composition of lambs. Anim.Feed Sci.Technol. 127: 175-186. https://doi.org/10.1016/j.anifeedsci.2005.08.013

McNiven, M. A., J. L. Duynisveld, T. Turner, \& A. W. Mitchell. 
2011. Ratio of n-6/n-3 in the diets of beef cattle: Effect on growth, fatty acid composition, and taste of beef. Anim. Feed Sci.Technol. 170: 171-181. https://doi.org/10.1016/j. anifeedsci.2011.09.006

Ramprasath, V. R., D. D. Buckley, J. E. Heubi, P. J. H. Jones, \& L. A. Woollett. 2012. Decreased plasma cholesterol concentrations after pufa-rich diets are not due to reduced cholesterol absorption/synthesis. Lipids 47: 1063-1071. https:// doi.org/10.1007/s11745-012-3708-8

Rufino, M. d. S. M., J. Pérez-Jiménez, M. Tabernero, R. E. Alves, E. S. De Brito, \& F. Saura-Calixto. 2010. Acerola and cashew apple as sources of antioxidants and dietary fibre. Int.J.Food Sci.Technol. 45: 2227-2233. https://doi. org/10.1111/j.1365-2621.2010.02394.x

Salinas, J., R. G. Ramırez, M. M. Dominguez, N. Reyes-Bernal, N. Trinidad-Larraga, \& M. F. Montano. 2006. Effect of calcium soaps of tallow on growth performance and carcass characteristics of Pelibuey lambs. Small Rum. Res. 66: 135139. https://doi.org/10.1016/j.smallrumres.2005.07.058

Silva, R. R., L. B. O. Rodrigues, M. d. M. Lisboa, M. M. S. Pereira, \& S. O. d. Souza. 2014. Conjugated linoleic acid
(CLA): A review. International Journal of Applied Science and Technology. 4: 154-170.

Smith, S. B., C. A. Gill, D. K. Lunt, \& M. A. Brooks. 2009. Regulation of fat and fatty acid composition in beef cattle. Asian-Australas. J. Anim. Sci. 22: 1225-1233. https://doi. org/10.5713/ajas.2009.r.10

Tahuk, P. K. \& A. A. Dethan. 2010. Performance of Bali bull in greenlot fattening by farmers when rainy season in Timor island. J. Indon. Trop. Anim. Agric. 35: 257-261. https://doi. org/10.14710/jitaa.35.4.257-261

Voigt, J., S. Kuhla, K. Gaafar, M. Derno, \& H. Hagemeister. 2006. Digestibility of rumen protected fat in cattle. Slovak J. Anim. Sci. 39: 16-19.

Wina, E., Y. Widiawaty, B. Tangendjaja, \& I. W. R. Susana. 2014. Supplementation of calcium fatty acid to increase milk production and performance of lactating dairy cow. JITV. 19: 287-293.

Wina, E., D. Yulistiani, I. W. R. Susana, \& B. Tangendjaja. 2012. Improving microbial protein synthesis in the rumen of sheep fed fresh tofu waste by crude tannin extract of acacia mangium. JITV 17: 207-214. 